\title{
A national parkless Northern Ireland: the tourism resource paradox and the implications for sustainability
}

\author{
J. P. W. Bell \\ School of Planning Architecture and Civil Engineering, \\ Queen's University Belfast, Northern Ireland
}

\begin{abstract}
This paper explores the 'resource paradox' concept as it relates to predicted increased tourism demands on the Northern Irish countryside and the need to harness the economic opportunities presented by tourism whilst avoiding the simultaneous destruction of precious landscapes; national park designation potentially offers one mechanism for managing this impending paradox. The Mournes case study is drawn upon to highlight how local governance challenges represent a potential obstacle to securing widespread stakeholder support for the sustainability principles associated with contemporary national park models.
\end{abstract}

Keywords: sustainable development, national park, resource paradox, environmental governance.

\section{Introduction}

This paper will firstly chart the emergence of sustainable development in a global context before examining its influence on protected area management in terms of widening the remit of protected areas to include people orientated objectives. Secondly, the role of national parks as global economic generators will be discussed in the context of the 'resource paradox'. Focus will then revert to Northern Ireland where economic orientated governmental priorities provide the basis for discussing the impending resource paradox in Northern Ireland, a region heavily dependent on countryside tourism in its quest for economic growth. Finally, the paper will draw on a recent consultation process, relating to a proposed national park, undertaken in the Mourne Area of Outstanding Natural Beauty (AONB) to discuss the governance challenges associated with 
designating national parks in Northern Ireland, potentially a prerequisite for more sustainable countryside management.

\section{Sustainable development and conservation}

National Parks represent one category of protected area and have 'long been seen as jewels in the crown of nature conservation' [1]. However, the principle of designating protected areas is often perceived to reflect regional, national and particularly international needs at the expense of local subsistence needs resulting in local frustrations stemming from what are perceived to be 'externally imposed priorities' [2]. As a consequence some rural communities have traditionally viewed pronouncements regarding national park designation as the 'voice of doom' [3]. Others argue that management of natural areas has changed significantly from the strictly protectionist, 'keep people out mentality' referred to as 'fortress conservation' $[4,5]$ towards a 'new conservation' which integrates conservation with socio-economic factors [6]. This broader conservation agenda has been fashioned by a number of global international movements. Since the first World Conservation Strategy (1980) and publication of Our Common Future [7] followed by the Fourth Congress on National Parks (1992), it has been recognised within the environmental community that environmental protection should be integrated with socio-economic, cultural and political considerations [8] both within and outside the protected area. The Brundtland Report (WCED, 1987) recognised the importance of public involvement in policy and practice if sustainable development was to be achieved: 'The law cannot enforce the common interest. It principally needs community knowledge and support, which entails greater public participation in the decisions which affect the environment. This is best achieved by decentralising the management of resources upon which local communities depend and giving these communities an effective say over the use of resources. It will also require promoting citizens' initiatives, empowering people's organisations, and strengthening local democracy' [7]. The importance of public participation was reflected at the Rio Earth Summit (1992) which further challenged the strictly protectionist model of conservation through Local Agenda 21 [9]. It emphasised the importance of incorporating new bottom-up forms of participation and involvement of citizens, communities and NGO's in resolving potential conflicts between the environment and development $[4,10]$. National park purposes have evolved to the extent that they are increasingly viewed as a mechanism for delivering sustainable development goals.

\section{Sustainable development: the broadening purposes of protected area management}

The global emergence of sustainable development [11] as the overriding principle for directing future international development has led to greater acknowledgement of the importance of 'landscape' and this is reflected by the broadening of IUCN designations to include category $\mathrm{V}$ designations $[8,12]$. 
There has been a theoretical shift in Western Europe from 'land protection' towards establishing 'protected landscapes' with increased attention to the importance of 'landscape' as a management category [13]. Phillips [14] identifies two key reasons for this growing recognition; firstly, the realisation that pursuing conservation objectives alone within parks or reserves is not feasible and secondly the growing acknowledgement of the importance of involving local people residing within or outside protected area boundaries in the management of protected areas. Category $\mathrm{V}$ designations require a management approach which incorporates social, economic and cultural interests and are therefore suitable for multi-functional landscapes which possess a mosaic of interest groups. Furthermore, category $\mathrm{V}$ designations are particularly attractive for many countries as they offer a mechanism for contributing to the realisation of sustainable development objectives. Many countries still classify their category V designations as 'national parks' which has resulted in their establishment in richly inhabited areas where strict conservation goals are potentially compromised by socio-economic and cultural considerations. National parks are now commonly established in multi-functional rural areas or humanised landscapes; the landscapes typically found in Northern Ireland.

\section{National parks as economic generators: implications for sustainability}

The national park concept has evolved to the extent that many have become major national and local economic generators through tourism. Whilst fulfilling their primary aim to conserve areas of environmental significance, protected areas can provide a marketable commodity through tourism. Although national parks were traditionally designated to primarily enhance environmental protection, models of national parks have evolved to incorporate, to varying degrees, social and economic interests. Even from their inception in the USA, national parks were recognised for their vast tourism potential [15, 16]. Many national parks have become key economic generators through growth of the nature based tourism industry [3, 17]. While McCool [18] gave little support to the belief that designating areas lead to a rise in visits, a more recent study by Fredman et al. [19] found a 40\% increase in visitation levels following National Park designation in Sweden. Commodification of nature [20-22], which views natural resource usage through a lens of economic exploitation, could be viewed as contradictory to the traditional concept of designating protected areas in the first place. This trend of utilising protected areas as economic tools is evident across the world [1, 20, 21, 23]. In light of the potential financial spin-offs associated with national park designation, balancing the interests of socioeconomic development with environmental protection has become a major challenge for management of protected areas worldwide. This challenge is magnified within multifunctional, inhabited landscapes where the social and economic futures of local communities are dependent on effective management of competing interests to derive multiple benefits from the landscape. 
These dilemmas can be conceptualised through the 'resource paradox' [2426] which relates to the use versus overuse scenario; natural areas offer a resource to be marketed, yet overuse (potentially through tourism) could destroy the natural beauty upon which the tourist experience depends, thereby jeopardising future tourism. Just as issues have been raised regarding the oxymoronic nature of the term sustainable development [27, 28], similar contradictions emerge in the context of managing diverse and potentially irreconcilable interests within protected areas. Alternative phrases have been used to conceptualise the threats posed by unregulated tourism development. In reference to a document produced by the European Federation of Nature and National Parks of Europe (Loving Them to Death, 1993), Hamin [13] identifies the possibility of "loving our parks to death" (p350) and allowing scenic areas to become 'environmental sacrifice zones' (p350). Furthermore, the hypothetical "tourist area cycle of evolution", developed by Butler [29] suggests that the resource base can become quickly eroded through unregulated tourism.

\section{The Northern Irish context}

Currently no national parks exist in Northern Ireland despite numerous designation attempts stemming back as far as 1947. Failure to designate national parks in Northern Ireland can be attributed to, amongst other issues, strong landowner opposition and alternative political priorities (dealing with civil unrest) [30]. Recent attempts to designate the Mourne area stalled because of political hesitation in the face of local landowner objection and a heavily criticised public consultation [31-33]. Whilst primary legislation still exists to designate national parks in Northern Ireland (Initially via the Amenity Land Act (NI) 1965 and more recently through the Amenity Lands Order (NI) 1985) an obvious gap in the legislation still exists; there is no provision for powers or mechanisms for national park management.

While civil unrest contributed to environmental neglect in Northern Ireland [30] the prolonged violence and political instability also had a clear economic impact on the region [34]. Emerging from four decades of sectarian conflict, the Northern Ireland Programme for Government [35] outlined the importance of enhancing socio-economic fortunes [35] through maximising the value of existing assets. Whilst development of urban areas is seen as critical to achieving socio-economic and cultural renewal, rural areas also represent a means for instigating regional economic renewal. Indeed, a discussion paper produced by the Environmental Policy Group (2004) recognised the dependence of the Northern Irish tourism industry on countryside areas and particularly the major tourist destinations which lie inside areas currently designated as AONB's: 'tourism in Northern Ireland depends largely on the quality of the countryside, its natural attractions and its distinctive cultural heritage and many visitor destinations are within AONB 's' [36].

Due to thirty years of underinvestment tourism has the potential to grow faster in Northern Ireland than elsewhere in the UK [37]. Furthermore, the government aim to double tourism revenue by 2020 through increasing visitor 
numbers from 3.2 million to 4.5 million [37]. Given that the tourism industry in Northern Ireland is heavily dependent on natural heritage the potential for tourism induced destruction of natural resources is heightened. The countryside tourism industry subsequently becomes threatened through self-destruction; this conundrum is conceptualised through the 'resource paradox' and is referred to in a publication of the Environmental Policy Group (NI): 'National Park designation may help retain the landscape quality required to attract tourism and may increase visitor numbers to designated areas, as national parks are often a 'must see destination' [36].

It is questionable whether increasing visitor numbers is compatible with retaining landscape quality. Currently, AONB represents the highest level of landscape protection in Northern Ireland. AONB management bodies in Northern Ireland have no statutory management powers, so it is questionable whether protected areas are being afforded adequate landscape protection and whether sufficient funding is available to manage these natural resources [38]. The Mourne Heritage Trust, the body responsible for managing the Mourne mountains, has expressed concerns regarding their ability to manage the rapidly deteriorating Mourne environment on diminishing resources [32]. Whilst the label of a national park has the potential to attract unsustainable tourist numbers $[3,17]$ it could also provide structures and mechanisms to actively manage tourism and safeguard natural resources. There is a delicate balance to be struck between enhancing/protecting the natural environment and maximising the opportunities presented by new rural economies such as tourism. National parks potentially offer one mechanism for managing or exacerbating this potential 'resource paradox'. Multi-purpose management within deeply contested protected areas could ultimately be viewed as a sustainability challenge based on managing the tensions between the three principles of sustainability. The following section will introduce the Mournes case study before drawing on interview findings and further secondary document analysis to assess the governance challenges associated with a recent attempt to proceed towards national parks designation and discuss the resulting sustainability challenge.

\section{The Mourne case study}

\subsection{An internationally significant area}

Owing to its rich natural heritage, the Mourne AONB boasts numerous International, National and European designations, including Ireland's first National Nature Reserve at Murlough Bay. An area covering approximately $570 \mathrm{~km}^{2}$ was designated as an AONB in 1965 and re-designated in 1986. In addition to biodiversity, the area has a rich legacy of human settlement etched indelibly across the landscape. Crucially, 50,000 people still reside within the Mourne and Slieve Croob area occupying a number of small and medium sized settlements and a sizeable proportion of dispersed rural dwellings [39]. Meanwhile there is a varied ownership pattern; Mourne Trustees, alongside the Water Service, the Forest Service and the National Trust own large tracts of the 
High Mournes, while the entire area of the Mournes consists of over 1500 private farmers or landowners.

This varied landscape has acquired different land uses as a result of the economic, environmental and social forces impacting on the area. While continuing to sustain traditional economies; industries such as agriculture $(53 \%$ of the land is actively farmed with an average farm holding size of 15 hectares [40]), fishing, forestry and small scale quarrying, the Mournes also have a distinct recreational legacy. The Mournes, readily accessible from both Dublin and Belfast, have become a primary tourist destination in Northern Ireland, with approximately 150,000 visitors per annum [41]. The significance of the Mournes to the tourism industry in Northern Ireland was recognised by the Tourist Board (NITB) which selected the Mournes as one of five signature projects. Indeed tourism is now an economic cornerstone for the Mourne area contributing significantly to local employment and business revenue [41].

The multi-functional dimension of the Mournes, comprising distinct social, economic and environmental functions, combined with the peculiar ownership pattern, creates a highly complex and contested terrain. The challenges of accommodating diverse and often competing interests surfaced during recent national park discussions [31]. One particular conflict provides the primary focus of this paper; that is the relationship between the conservation interest and the economic based tourism interest. Speculative building, commercial enterprises such as quarrying and tourism are placing a significant burden on the Mourne landscape through erosion, disturbance of wildlife, congestion and litter [42]. It has been recognised that 'a sustainable approach to the development of tourism in the area needs to be established to manage these (tourism related) impacts' [42]. With an apparent management deficit in the Mournes [32] the prospect of increased tourist numbers represents a potential threat to its environmental integrity. It is questionable whether the Mourne Heritage Trust is capable of providing the integrated and pro-active management to sustainably handle current let alone increased visitor levels. The structures and management arrangements associated with national parks represents one option for better managing tourism pressures. However, distaste for the current (low) levels of management in the Mournes came across strongly during interviews with local stakeholders. Enhancing management in Mourne, through national park designation, is therefore unlikely to gain widespread landowner support. The prospects of overcoming such governance challenges will now be referred to in the context of recent attempts to proceed towards the introduction of a national park in the Mournes.

\subsection{A Mourne national park: the debate re-opened}

In 2002 a government commissioned report [43] concluded that the Mournes represented the most appropriate location for a national park in Northern Ireland [44]. An independent body was established in October, 2004; the Mourne National Park Working Party (MNPWP) comprising representatives from a range of organisations and interest groups. The MNPWP was asked by government to commission research examining possible national park 
boundaries, to develop proposals regarding the possible management structure and conduct a formal consultation before reporting back to the Minister. The purpose of the MNPWP consultation was clearly not to gauge levels of support for a national park by conducting a referendum style 'yes' or 'no' national park consultation [39], but rather to "open up the debate" (p13) through a process of engaging with and informing the public as well as hearing views on a proposed national park boundary and the possible impacts of designation.

\subsection{The consultation process}

Armed with the findings from various consultants' reports and a possible boundary the MNPWP launched a formal consultation on $1^{\text {st }}$ September 2006 lasting until $31^{\text {st }}$ January 2007 targeted specifically at the local Mourne population. Following a widespread leaflet drop, the consultation comprised a series of public meetings and specific sector meetings whereby a panel of experts were available to discuss issues raised. Over 1150 people attended the ten public consultation events, 79 written submissions were received and 3 petitions submitted. The findings from these information gathering processes culminated in the Working Party's Report to the Minister [39] which was submitted in September 2007, comprising 29 core recommendations.

\subsection{A critique of the working party consultation}

In their report, the MNPWP recognised a number of weaknesses associated with the consultation process and subsequent commentators have identified numerous shortcomings. This section will firstly outline the core weaknesses of the consultation as identified in the MNPWP report, before drawing on some wider literature and further interview responses to explore aspects of this criticism in more detail.

The first acknowledged criticism by the MNPWP relates to 'coverage'. While stating that the consultation was wide reaching, the MNPWP notes that criticism was directed at the fact consultation meetings were limited to the Mourne locality [39]. This issue has resonance with a key debate in environmental management regarding the extent to which regional or national interests should be considered within protected area management [45]. A Northern Ireland wide consultation was outside the remit of the MNPWP, whose operational effectiveness appears to have been somewhat constrained by both time and money [32].

The second criticism acknowledged by the MNPWP relates to the format adopted during the consultative meetings. It was recognised that 'the meeting format did not facilitate the expression of a range of views' [39] with one interviewee describing the public meetings as "farcical". A further interviewee described how he felt "rail roaded to an extent that no matter what you said they were shouting and opposing it you know, but you didn't get a fair crack of the whip........ a lot of the open meetings were commandeered by the farming community". Some stakeholders perceived the traditional top table meeting format of experts answering to a crowd to be inappropriate and instead 
championed a surgery, drop-in style approach (interview with Mr David Fox). Indeed, all stakeholders interviewed appeared to voice dismay at the way in which the consultation meetings were conducted. Disruptive behaviour, a lack of respect towards differing views and an absence of meaningful dialogue are some of the factors which mired the meetings [31-33]. A particularly 'strong and vocal 'no' campaign' [39] was evident throughout the process, mainly directed by an element of the local farming community. Notably, support for the MNPWP from this sector was eroded following a radio interview with the chairman of the MNPWP which created a perception within the farming community that the chairman was favourable towards the idea of national park [31]. Compounded by a series of Ministerial position statements, this radio interview created a feeling that a national park was a 'done deal' [32, 39]. While some have labelled the vociferous 'no' campaign as constituting an unrepresentative section of the farming community [33] opinion was split between interviewees regarding the true extent of the opposition to a national park. One interviewee commented; "the pro voice is stronger than the no voice in numbers but the tactics that the no vote uses has got them a bigger representation than I think they're worth". Regardless of the true extent of the opposition, the strength of the 'no' campaign and the powerful position they adopted had stark ramifications for the entire consultation process. Meaningful engagement with the farming community was limited and the 'no' campaigners showed reluctance to engage in the consultation meetings. Their actions appeared to have an intimidatory effect on other sections of the community. For example, interviewees reported threats to boycott businesses if chambers of commerce supported a national park, and members of the MNPWP and other local representatives were challenged somewhat aggressively in the course of their day-to-day business. Claire Maxwell, a local business woman commented; "I felt intimidated by the other side and I had received phone calls and things like that telling me to change my mind, what am I talking about; things like that you know." Meanwhile, it was felt by two stakeholders that there was a paucity of ordinary people involved in the consultation process; that the moderate voice of "people who weren't so zealous that they wanted to go to a meeting and shout the odds and they weren't so much in favour that they felt the need to stand up for the idea. They're just you know they're the people walking up and down the street...... who weren't really heard" (Mr. David Fox). A lack of engagement with the general public could have stemmed from a widespread perception within the local community that 'this issue doesn't affect me' and a belief that this was a ding dong battle between conservationists and landowners (interview with the chairman of USPC). Indeed one member of the MNPWP explained how a member of the public commented on how they thought the public meetings were for landowners only.

McAreavey [32] refers to the power differentials in a somewhat different context to those inter-communal power relations as evidenced above. McAreavey [32] recognises the particularly influence of the government who administered the consultation through a superimposed body (the Working Party); a rather different but equally salient factor which had a similar impact in terms of 
constraining certain individuals within the consultation process. One interviewee commented that "farmers are conservative and they don't like change....people don't like groups who turn up to organise you, that's why there is such incredible widespread dislike for the Mourne Heritage Trust"' (Mr Gareth McGrath) while another interviewee compared the dominant voices within the MNPWP consultation, to the Tea Party activists in America describing them as "the very reactionary right wing of both sides of our community; the Nationalists and the Unionists, the very anti-change sort of brigade" (Mr. David Fox). The latter suggested that much of the opposition to the national park proposal came from rather conservative elements of the community who tend to take a strong ideological or gut reaction against government led or collective initiatives, to the point of resisting something almost for the sake of it or in a self-interested fashion. This anti-government sentiment which came across in a number of subsequent interviews may explain the apparent disdain for the idea of being 'managed' or introducing enhanced management in the Mournes (as suggested by Mr. Gareth McGrath), through what are perceived to be externally imposed management arrangements. While certain individuals and stakeholder groupings acquired more dominant positions and exerted their influence within the local community (an example of horizontal or inter-communal power differentials) this power was seemingly mobilised in response to the unreasonable way in which the Mourne national park idea was initiated and pursued (vertical power) by government. The vociferous and dominating nature of the anti-national park voice which contributed to suppressing widespread public involvement, appears to have been a reaction to the way government initiated and conducted the process. The actions of government appear to have fuelled a long standing distaste toward government and from an early stage the consultation was seen as another example of government wielding an inappropriate level of influence.

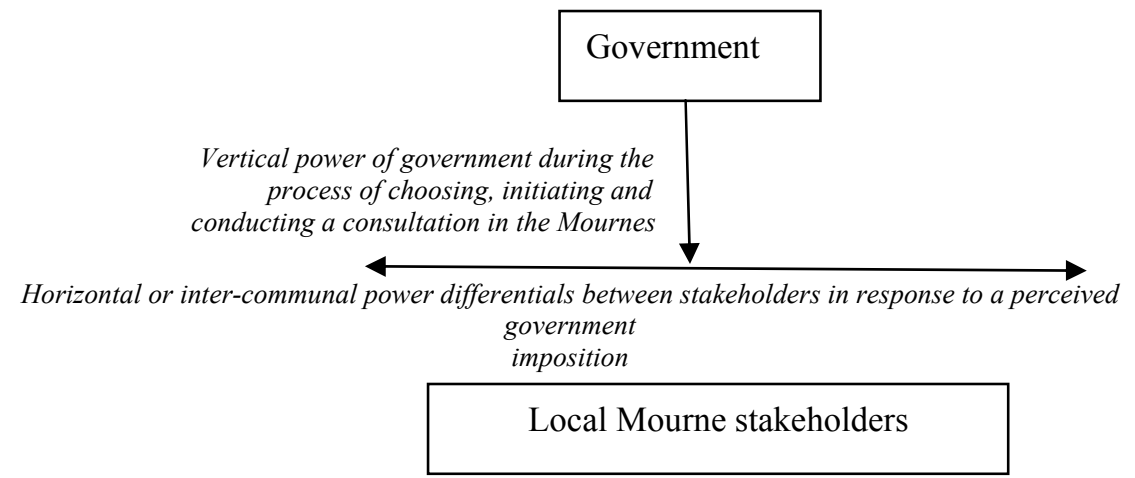

Figure 1: Demonstrating the vertical and horizontal power relations affecting the Mourne national park consultation process.

A third key criticism of the consultation process again relating to the consultation meetings, was that they offered little in the way of information or answers to questions posed $[31,32,39]$. However it appears that different 
stakeholder understandings of the purpose of the consultation subsequently generated varying expectations of the consultation process. The Working party cited the fact that they were commissioned to 'open up the debate' and report on local views, rather than consult on concrete proposals, as a reason for having a lack of information. Indeed, the consultation was undertaken within a legislative vacuum which meant the Working party was unable to provide an outline of possible national park management structures. This lack of information appears to have critically undermined the consultation, through failing to allay fears within, particularly, the landowning and farming community. These perceived, or possibly at times irrational or imagined fears, [31] were allowed to fester perpetuating a 'fear of the unknown' [31]. Sections of the landowning community maintained their stance of outright opposition, unwilling to engage in constructive dialogue or listen to possible solutions to concerns (interview with Mr. David Fox), particularly around access. While the perception that a decision to designate had already been made appears to have been particularly damaging to the consultation, the unwillingness within parts of the community to discuss the issue, suggests that resentment towards a Mourne national park stems from something deeper than the those concerns which are typical of many rural areas or national parks in the UK.

Following completion of the official Mourne National Park consultation period in 2007 it was reported that 'the gap between supporters and critics of the national park seems to be widening' [46]. The notable failures inherent in the MNPWP consultation, and the disillusionment evident in the local community, could undermine future efforts to proceed towards a national park designation. Govan et al. [47] have observed how within a national park context, if a sense of community disempowerment takes root, it can take many years to overcome. Prospects of designating a Mourne national park in the immediate future could therefore be severely hampered, as a result of this initial, seemingly flawed [31, $32,46]$, consultation process. However, the context within which the last consultation was conducted was one of relative economic prosperity. Changing global economic circumstances were cited by one interviewee as a possible catalyst for generating more meaningful engagement from the landowning and farming community. Rather than allow a number of dominant individuals to act on their behalf presenting a front of outright aversion; in light of prolonged economic austerity, previously silent stakeholders may now be more willing to engage constructively in discussions to assess the possible benefits of a national park (interview with Mr. David Fox). While there was unanimous agreement amongst interviewees that economic considerations should not be the sole driving force behind designation there was acknowledgment amongst those interviewed that if politicians decided to take forth a national park designation in Northern Ireland it would more than likely be to fulfil an economic agenda. As Mr. Fox explained: "I suppose this is probably my concern, now that government has said it does want to go for national parks in Northern Ireland my feeling is that it is based largely on an economic rationale, which is fine....but I would be a wee bit concerned that it's too much seen as it's a money spinner as opposed to protection". 


\section{Conclusion}

In light of the ambitious governmental desire to double revenue from tourism over the next ten years [37], it is imperative that this engine of economic growth is managed in a way that is both socio-economically beneficial and environmentally sensitive. Due to the underdeveloped nature of tourism in Northern Ireland, the Department of Enterprise, Trade and Investment (DETI) have predicted a faster rate of tourism growth in Northern Ireland, compared to other UK regions [37]. Tourism is clearly an instigator of change [48] and the potential for rapid growth in Northern Ireland presents both an opportunity and a threat. The structures associated with a national park offer one mechanism for managing tourism growth whilst maintaining and enhancing the natural resource base to secure the longevity of socially acceptable, economically viable and environmentally sensitive tourism in Northern Ireland. Significant opposition to the idea of national park appears to exist within the Mourne locality and recent consultation did little to alleviate local and often irrational fears [31]. On the basis of the best practice advice offered by Govan et al. [47] it could take many years to regain the trust of a disillusioned and divided local community.

Govan et al. [47] have stated the importance of securing political support for national parks. Prospects of proceeding towards national park designation or providing some form of enhanced, pro-active management of the Mournes could therefore hinge on the willingness of elected representatives to move the issue forward. Greater recognition of the economic benefits that national park can bring could be a motivating factor in galvanising the national park debate at government level, given that the Northern Ireland Programme for Government [35] has identified 'growing the economy' (p2) as its top priority. Not only do national parks contribute to enhanced landscape protection but potentially they offer a mechanism of socio-economic renewal in rural areas. However, political hesitancy in the face of landowner opposition [30] has, for a number of decades, undermined attempts to introduce national parks in Northern Ireland. Perhaps, as in Scotland, in the aftermath of devolution, politicians may view national parks as a potential symbol of political progress $[4,49]$. However, the evidence to date suggests that devolved government in Northern Ireland could have the reverse effect. For example, the abandonment of PPS14 in favour of a more relaxed or balanced rural planning policy (PPS21) supposedly giving greater consideration to local socio-economic needs, raises a possible environmental dilemma associated with devolved governing. Whilst contributing to potentially more democratic decision making and policy making (representing local priorities), local socio-economic considerations potentially take precedence over wider environmental concerns. If harnessed correctly national park offers a mechanism for managing the tourism resource paradox and achieving socio-economic and environmental goals in tandem. While Scottish devolution was a catalyst for national park establishment $[49,50]$, it could be argued that devolution has potentially had an obstructive influence on enhancing countryside protection in Northern Ireland. It is still early days in the life of the Northern Ireland 
Assembly but it remains to be seen whether this trend will be reversed in the near future.

\section{References}

[1] Benediktsson, K., Porvaroardottir, G., Frozen opportunities? Local communities and the establishment of Vatnajokull National Park, Iceland, Mountains of Northern Europe. 'Conservation, Management, People and Nature, ed. Thompson, D.B.A., Price, M.F., Galbraith, C.A., Scottish Natural Heritage: Edinburgh, pp. 335, 2005.

[2] Pimbert, M. and Pretty, J., Diversity and sustainability in community based conservation. Paper presented at the UNESCO-IIPA regional workshop on Community-based Conservation, February 9-12, 1997; Diversity and sustainability in community based conservation. Available at http://www.iied.org/pubs/pdfs/G01094.pdf: 1997.

[3] Hamin, E.M., The US National Park Service's partnership parks: collaborative responses to middle landscapes. Land Use Policy, 18 pp. 123135, 2001.

[4] Warren, C. Managing Scotland's Environment. Edinburgh University Press: Edinburgh, 2009.

[5] Lister-Kaye, J., The enjoyment and understanding of nature and wildness, Enjoyment and understanding of the natural heritage, ed. Usher, M.B., The Stationary Office: Edinburgh, pp. 3-10, 2001.

[6] Brown, K., Innovations for conservation and development. Geographical Journal, 168(1), pp. 6-17, 2002.

[7] WCED, Our Common Future. Oxford University Press: Oxford, 1987.

[8] Barker, A., Stockdale, A., Out of the Wilderness? Achieving sustainable development within Scottish national parks. Journal of Environmental Management, 88(1), pp. 181-193, 2008.

[9] O'Riordan, T., Voisey, H., The Politics of Agenda 21, The Transition to Sustainability: The Politics of Agenda 21, ed. O'Riordan, T., Voisey, H., Earthscan: London, 1998.

[10] Lafferty, W.M., Eckerberg, K., The Nature and Purpose of 'Local Agenda 21', From the Earth Summit to Local Agenda 21: working towards sustainable development, ed. Lafferty, W.M., Eckerberg, K., Earthscan: London, pp. 1, 1998.

[11] O'Riordan, T., Voisey, H., The transition to sustainability: the politics of Agenda 21 in Europe. Earthscan Publications: London, 1998.

[12] Ogden, P., Protected landscapes: their role in promoting the sustainable use of agricultural use of land. Parks, 13(2), pp. 3, 2003.

[13] Hamin, E.M., Western European Approaches to landscape Protection: A Review of the Literature. Journal of Planning literature, 16 pp. 339, 2002.

[14] Phillips, A., Landscape approaches to national parks and protected areas, National parks and protected areas: Keystones to conservation and sustainable development, ed. Nelson, J.G., Serafin, R., Springer: Berlin, pp. 31, 1997. 
[15] Butler, R.W., Boyd, S.W. Tourism and National Parks: Issues and Implications. John Wiley: Chichester, 2000.

[16] Harroy, J.P., Tassi, F., Pratesi, F., Humphries, C., National Park's of the World. Orbis publishing: London, 1974.

[17] Reinius, S., W., Fredman, P., Protected areas as attractions. Ann Tourism Res, 34(4), pp. 839-854, 2007.

[18] McCool, S., Does Wilderness Designation Lead to Increased Recreational Use? Journal of Forestry, 83 pp. 39-41, 1985.

[19] Fredman, P.L., Hornsten, F., Emmelin, L., Increased Visitation from National park Designation. Current Issues in Tourism, 10 pp. 87-95, 2007.

[20] McIntyre, N., Jenkins, J., Booth, K., Global influences on access: the changing face of access to public conservation lands in New Zealand. Journal of sustainable tourism, 9(5), pp. 434, 2001.

[21] Healy, N., McDonagh, J., Commodification and Conflict: What Can the Irish Approach to Protected Area Management Tell Us? Soc Nat Resour, 22(4), pp. 381-391, 2009.

[22] Zimmerer, K.S., The reworking of conservation geographies: non equilibrium landscapes and nature-society hybrids. Annals of the American Association of Geographers, 90(2), pp. 356, 2000.

[23] Mbaiwa, J.E., The socio-economic and environmental impacts of tourism development on the Okavango Delta, north-western Botswana. J Arid Environ, 54(2), pp. 447-467, 2003.

[24] Plog, S.C., Why destination areas rise and fall in popularity. Cornell Hotel Restaur Adm Q, 14(4), pp. 55-58, 1974.

[25] Oliveira, J.A.P., Governmental responses to tourism development: three Brazilian case studies. Tourism Management, 24(1), pp. 97-110, 2003.

[26] Williams, P.W., Ponsford, I.F. Confronting tourism's environmental paradox: Transitioning for sustainable tourism. Futures, 41 pp. 396-404, 2009.

[27] Redclift, M.R., Sustainable development (1987-2005): an oxymoron comes of age. Horizontes Antropológicos, 12 pp. 65-84, 2006.

[28] Weaver, D.B., Tourism and the Elusive Paradigm of Sustainable Development, A Companion to Tourism, ed. Lew, A.A., Hall, C.M., Williams, A.M., Blackwell Publishing: Oxford, pp. 510-524, 2004.

[29] Butler, R., The concept of the tourist area cycle of evolution: Implications for management of resources. Canadian Geography, 24(1), pp. 5, 1980.

[30] Buchanan, R.H., Landscape. The recreational use of the countryside, Northern Ireland. Environment and Natural Resources, ed. Cruickshank, J.G., Wilcock, D.N., The Queen's University of Belfast: Belfast, pp. 265, 1982.

[31] Bell, J., Stockdale, A., Towards a multi-purpose model for the proposed Mourne National Park. Irish Geography, 42(3), pp. 293, 2009.

[32] McAreavey, R., Towards a Mourne National Park? Emergent prospects and pitfalls from articulating needs in a local context. Institute of Spatial and Environmental Planning, Queen's University Belfast: Belfast, 2010. 
[33] Rowan, E., Merging Collaborative Planning and Environmental Valuation; eliciting preferences for a national park designation in Northern Ireland. Queen's University Belfast: Belfast, 2009.

[34] Deloitte, Research into the financial cost of the Northern Ireland divide. Deloitte: London, 2007.

[35] Northern Ireland Executive, Programme for Government 2008-2011. Northern Ireland Executive: Economic and Policy Unit, 2008.

[36] Northern Ireland Environmental Policy Group, National Parks and other Protected Landscape Areas: A discussion of options for establishing national parks and managing other outstanding landscapes in Northern Ireland. Department of the Environment: Belfast, 2004.

[37] Department of Enterprise, Trade and Investment, A Draft Tourism Strategy for Northern Ireland to 2020. DETI: Belfast, 2010.

[38] Johnson, A., Northern Ireland's national park back in the wilderness, The Independent Media: London, 2009.

[39] Mourne National Park Working Party, Report to the Minister. Environment and Heritage Service: Belfast, 2007.

[40] Countryside Access and \& Activities Network, Mourne Area of Outstanding Natural Beauty Access Study. CAAN: Belfast, 2007.

[41] Buchanan, C. and Partners Ltd., Tourism in Mourne: Current and Potential Economic Impact. Author: Belfast, 2006.

[42] Mourne Heritage Trust, An Introduction to the Mourne Biodiversity Action Plan - A reflection of Mourne's Rich Natural Heritage. MHT: Newcastle (NI), 2007.

[43] Bungay et al., Special Places Need Special Care. Europarc: 2002.

[44] BBC, National park plan moves closer. 2002; 6th January, 2011Available at: http://news.bbc.co.uk/1/hi/northern ireland/2282701.stm.

[45] Warren, C., The 'natural': conservation management, Managing Scotland's Environment, ed. Warren, C., Edinburgh University Press: Edinburgh, pp. 214, 2009.

[46] Cassidy M., Community split over national park. 2007; March, 30th, 2010Available at: http://news.bbc.co.uk/1/hi/northern ireland/6388157.stm.

[47] Govan, H., Inglis, A., Pretty, J., Harrison, M., Wightman, A., Best Practice in community participation for National Parks. Scottish Natural Heritage: Edinburgh, 1998.

[48] Glasson, J., Godfrey, K., Goodey, B., Towards visitor impact management: Visitor impacts, carrying capacity and management responses in Europe's historic towns and cities. Avebury: England, 1995.

[49] Rennie, A., The importance of National Parks to nation building: support for the National Parks Act (2000) in the Scottish Parliament. Scottish Geographical Journal, 122(3), pp. 223, 2006.

[50] Thompson, N., The practice of government in a devolved Scotland: the case of the designation of the Cairngorms National Park. Environment and Planning C: Government \& Policy, 24(3), pp. 459-472, 2006. 